\title{
Isolation of Aeromonas hydrophila and Evaluation of Its Pathological Effects on Koi Fish (Cyprinus carpio)
}

\author{
Seyedeh Shiva Alavinezhad ${ }^{1}$ (D), Reza Kazempoor ${ }^{2 *}$ (D), Arman Ghorbanzadeh ${ }^{3}$, Ahmad Gharekhani $^{4}$ \\ 1. Department of Aquatic Health and Diseases, Faculty of Veterinary Medicine, University of Tehran, Tehran, Iran \\ 2. Department of Biology, Roudehen Branch, Islamic Azad University, Roudehen, Iran \\ 3. Department of Aquatic Health and Diseases, Faculty of Veterinary Sciences, Tehran Science and Research Branch, Islamic \\ Azad University, Tehran, Iran \\ 4. Department of Veterinary Medicine, Maku Branch, Islamic Azad University, Maku, Iran
}

$\underline{10.30699 / i j m m \cdot 15.4 .465}$

\begin{abstract}
In the summer of 2018, this study was performed on 50 Koi fish transferred to Razef Research Complex. In this study, after observing macroscopic symptoms in fish, including lethargy and immobility, imbalance, darkening of the skin, skin wounds, petechiae in the abdomen, opacity of the eye and anophthalmia, anorexia, and sitting on the bottom of the aquarium, sampling was performed to diagnose the pathogens and examine the pathological changes. According to microbial tests on skin samples and internal organs, Aeromonas hydrophila was reported, and septicemia in $48 \%$ of the studied fish. In necropsy specimens, the organs were pale, the liver was enlarged, and petechiae were observed on the surface of the liver. The microbial contamination also led to considerable tissue damages, including the destruction of gill filaments, nuclear pycnosis in the liver, and the infiltration of inflammatory cells into the heads of all fish. Considering the significant losses due to the pathogenicity of Aeromonas hydrophila in different fish species and the importance of Koi fish, observing quarantine and hygienic principles to prevent sepsis was very important. Early diagnosis and use of appropriate treatment protocols for this disease are recommended.
\end{abstract}

Keywords: Aeromonas hydrophila, Koi fish, Pathology

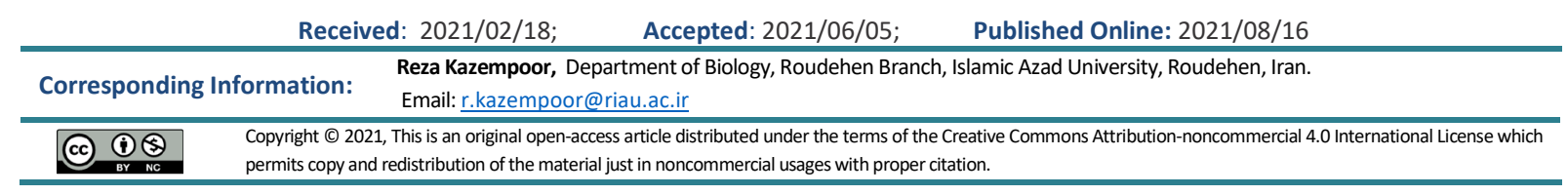

Use your device to scan and read the article online

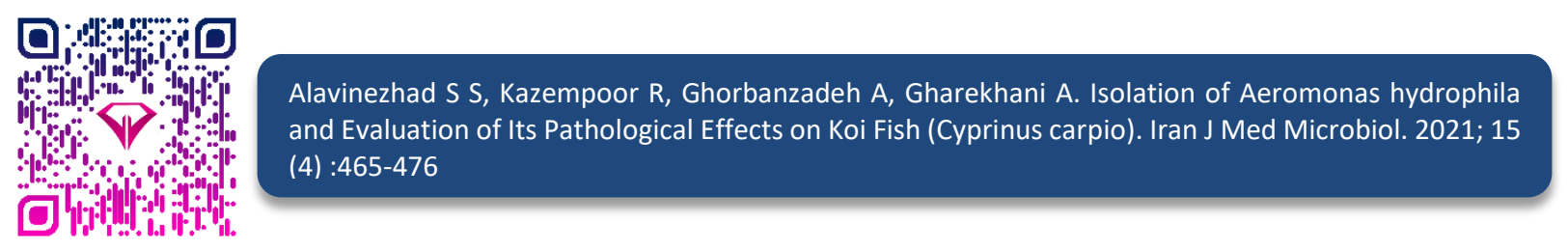

Download citation: BibTeX | RIS | EndNote | Medlars | ProCite | Reference Manager | RefWorks

Send citation to: $\otimes_{\text {Mendeley }} 2$ zotero $\overline{\text { Bi }}$ RefWorks

\section{Introduction}

Aeromonas hydrophila is a Gram-negative bacillus found in aquatic environments, drinking water, sewage, and food (1). This bacterium can be isolated from estuaries, seawater, and freshwater (1-3). Freshwater environments, especially those rich in mineral materials, are the natural habitat of $A$. hydrophila; however, recent evidence suggests that this organism can also be found as a part of intestinal flora in fish (4).

The bacterium is known to be a pathogenic microorganism in fish, causing a wide range of diseases, including motile Aeromonas septicemia in carp, tilapia, catfish, and salmon, the red spot disease in bass and carp, and wound-associated infections (e.g., Epizootic ulcerative syndrome) in catfish, cod, and carp (5). 
Aeromonas septicemia usually occurs when fish are under stressful conditions such as high-temperature and poor-quality water, hypoxia, parasitic infections, high density, manipulation, and transport $(6,7)$; it may cause chronic inflammation for several weeks, graduaIly increasing the mortality rate. Factors like mortality associated with this bacterial infection, its management, and its treatment costs, highly inflict the fish farming industry $(8,9)$. Also, $A$. hydrophila can cause localized tissue damage in the host, including tissue degeneration and inflammation $(10,11)$.

Another important point about this bacterium is that in addition to fish, it can lead to zoonotic disease in amphibians and reptiles, which can also be pathogenic for mammals, including humans $(2,8,11,12)$. In fact, it is known as an emerging pathogen for humans (1). Consequently, the presence of drug-resistant $A$. hydrophilic in aquariums becomes important regarding multiple public health aspects (13).

Koi (fancy carp Cyprinus carpio L. var. Koi) is an expensive ornamental freshwater fish that is often inflicted by infectious diseases, such as $A$. hydrophila, eventually leading to their death (14), raising environmental concerns (15) and zoonotic hazards (13). Based on the above and the importance of $A$. hydrophila infection in Koi fish, which leads to high mortality in fish, in the present study, we reported the isolation of $A$. hydrophila bacteria from the Koi fish transferred from farm ponds to the aquariums of a research center. The bacteria were identified using microbial culture methods, and pathological changes in the gills, liver, and kidneys were assessed to determine the pathological effects of this infection on this valuable ornamental fish.

\section{Case Report}

In the summer of 2017, 50 pieces of Koi fish (with an average weight of $25 \pm 2$ grams and a mean length of $24 \pm 3 \mathrm{~cm}$ ) were transferred from one of the concrete ponds of the Koi Fish Farming and Breeding Center in Shahriar city to the Razef Research Center, Tehran Science and Research Branch, Islamic Azad University, Tehran, Iran. Then, the fish were randomly divided into five tanks (170 L) (10 fish per tank). After a few days after the transfer, all the fish developed similar macroscopic symptoms, including darkening of the skin, abdominal petechiae, skin lesions, corneal opacity and anophthalmia, lethargy, immobility, imbalance, anorexia, and seating on the floor of the aquarium. After observing these clinical signs, we took the necessary measures (including autopsy for obtaining samples from the skin and internal organs for pathological and microbial examination). As this study was a case report, seven fish presenting these clinical signs were randomly caught from each tank (a total of 35 fish). After anesthesia by clove powder, sampling was performed to obtain specimens from the skin and internal organs and identify the pathogenic agent. All the histological and microbial examinations were conducted under completely sterile conditions.

Liver, gill, and kidney samples were initially washed with the physiological serum and then completely homogenized using a tissue homogenizer. Afterward, the specimens were cultured on Brain Heart Infusion Agar (BHI Agar) medium and incubated at $28^{\circ} \mathrm{C}$ for two days. After this step, the grown colonies were recultured on BHI Agar medium; the motile, oxidasepositive, and glucose fermenter bacteria suspected as Aeromonas spp., underwent further biochemical and physiological analyses. The confirmatory tests at this step included: $\mathrm{H}_{2} \mathrm{~S}$ production, urease test, citrate reduction, indole production, nitrate reduction, growth on MacConkey medium, and the fermentation of carbohydrates (glucose, inositol, sucrose, sorbitol, arabinose, and mannitol) (16).

For histological examinations, gill, liver and kidney samples were initially fixed in formalin buffer $10 \%$ for 48 hours. Then the fixed samples were placed in paraffin after dewatering and clearing with xylene. Tissue sections with a diameter of $5 \mu \mathrm{m}$ were prepared using a microtome device and stained by hematoxylin-Eosin (H\&E). The prepared histological slides were examined by optical microscope (Olympus BX51; Olympus, Tokyo, Japan) to evaluate pathological features (17).

The results of the microbial tests showed that $48 \%$ of septicemia cases (24 samples) were caused by $A$. hydrophila (Figure 1). In autopsy specimens, in addition to petechiae and skin darkening and ulcerative lesions, the internal organs were pale, and the liver was enlarged with observable petechiae on its surface (Figure 2). In the microscopic examination of the gills, we observed collapsed and swollen secondary lamellae, the swelling, and shortening of lamellae and their complete destruction, as well as the edema of gill filaments. In addition, the epithelial detachment was observed along with the detachment of the lamellar epithelium outer layer. Congestion was evident in the primary and secondary lamellae (Figure $3 \mathrm{~A}$ and $\underline{B}$ ). In the kidney, the infiltration of inflammatory cells (neutrophils) was evident in vessels and renal parenchyma (Figure 3C). The most prominent changes in the liver were irregular hepatic fibers, nuclear pyknosis, and cytoplasmic vacuolation. In addition, varying degrees of pancreatic cell degeneration were evident in some parts (Figure 3D). 

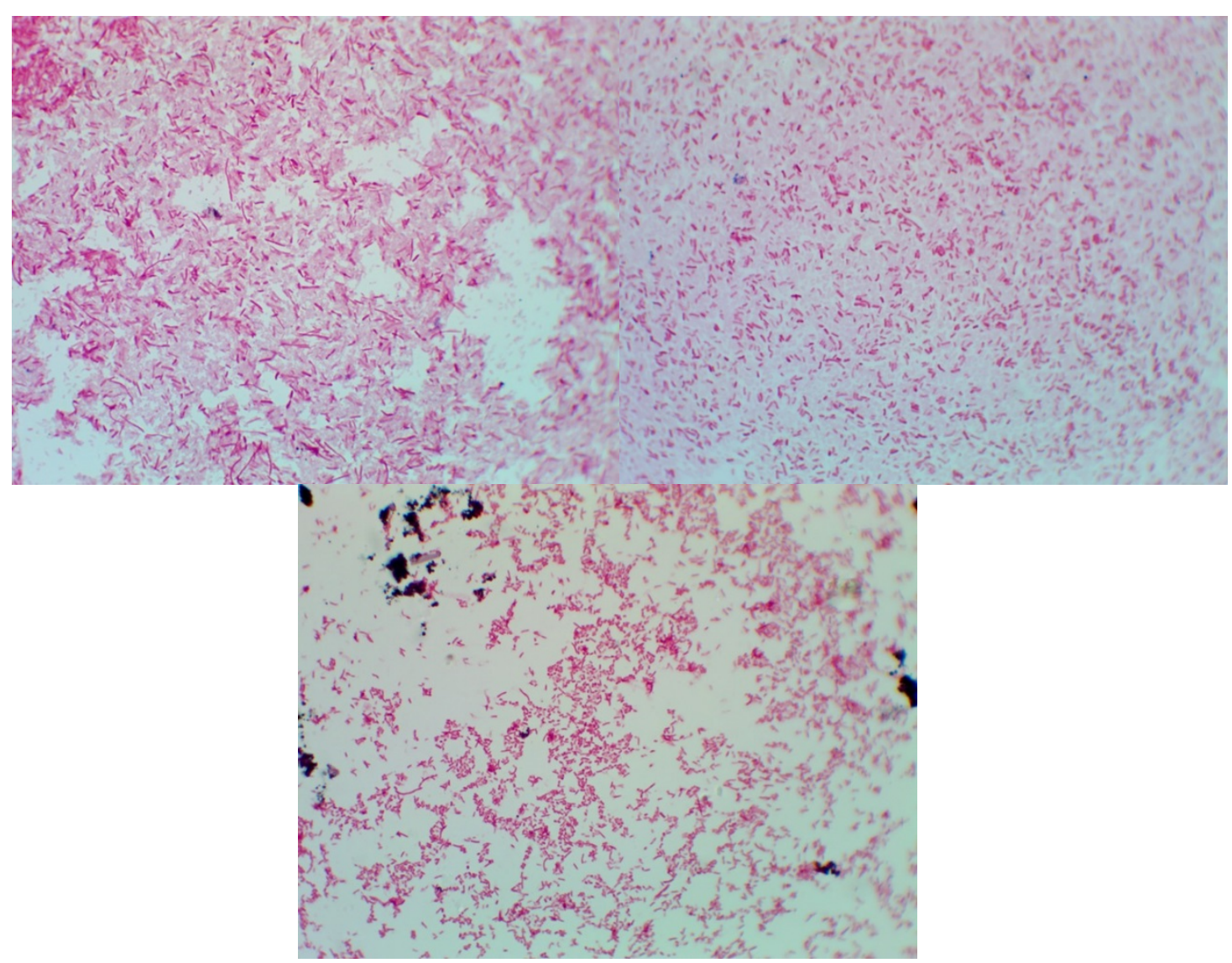

Figure 1. The identification of Aeromonas hydrophila bacterium in the studied samples

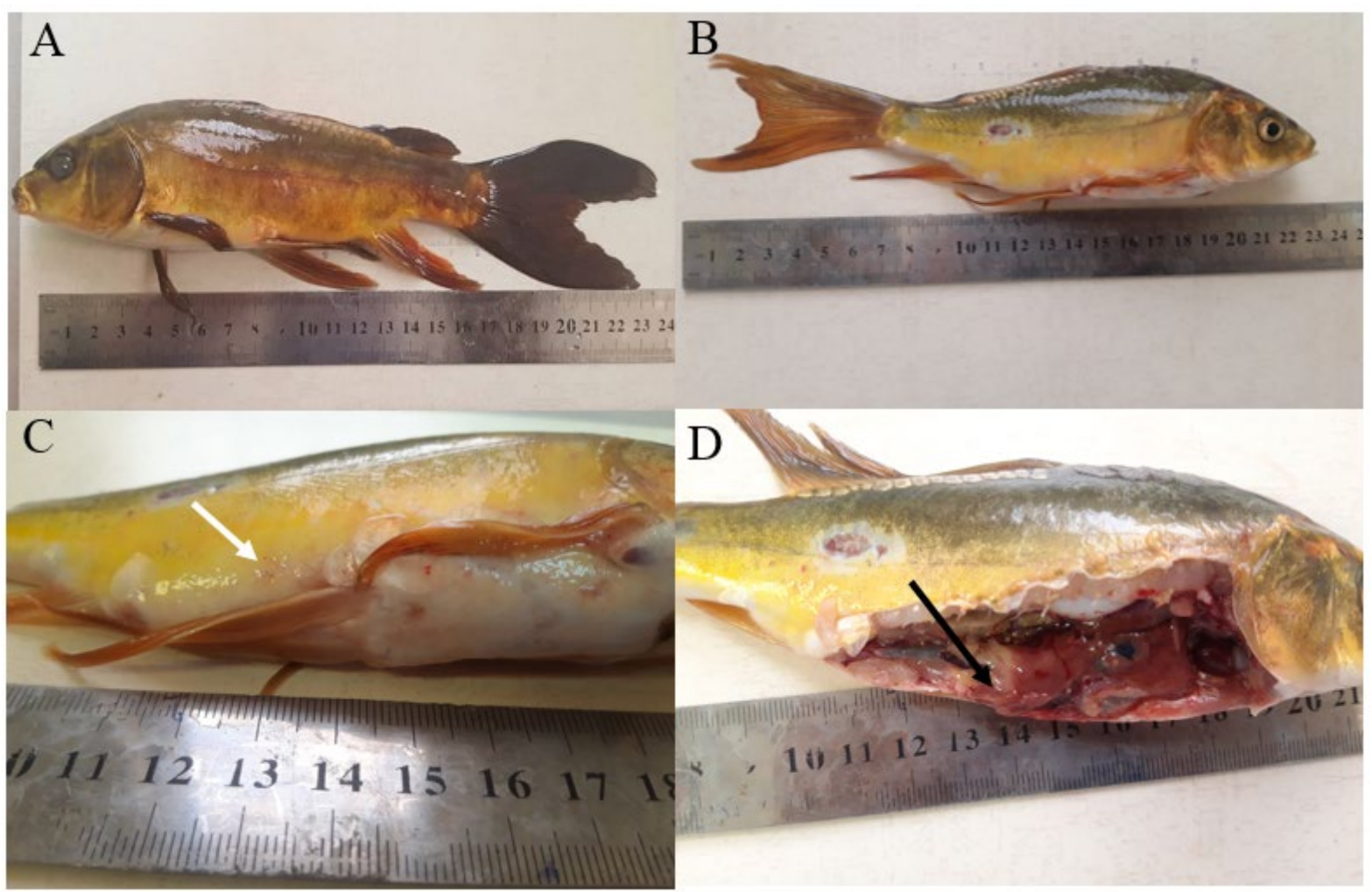

Figure 2. The darkening of the skin (A), ulcerative skin lesions (B), petechiae on the skin surface (the white arrow) (C), the enlargement of the liver, pale internal organs, and petechiae on the liver surface (the black arrow) (D). 

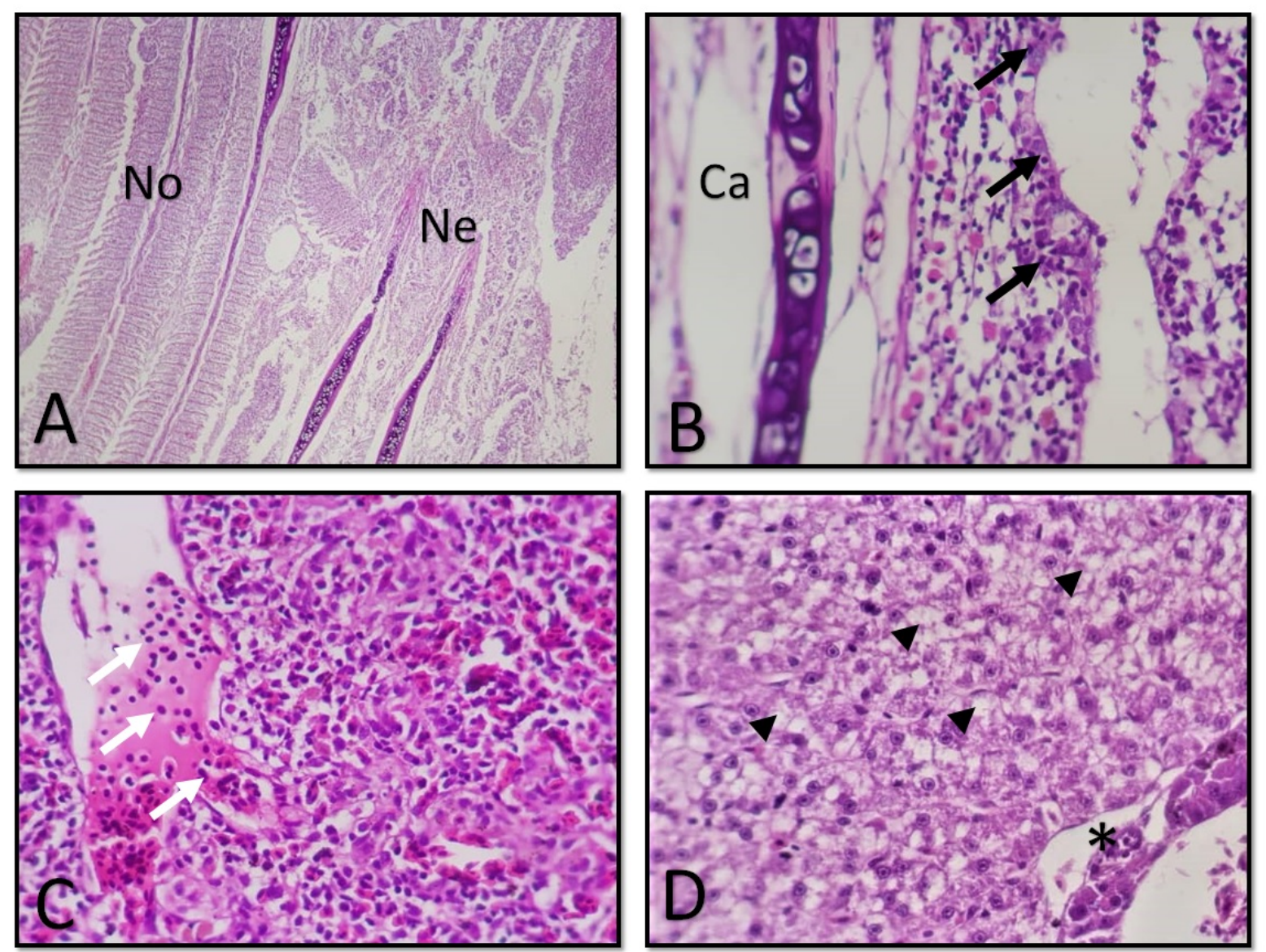

Figure 3. Gill, kidney, and liver histopathological examination. NO: normal gill blades, Ne: acute necrosis, Ca: gill cartilage, black arrow: the necrosis of epithelial and mucosal cells, white arrow: infiltration of inflammatory cells, arrow tip: the necrosis of hepatocytes, star: pancreatic cell degeneration. A: Gills (40X), B: Gills (400X), C: Kidney, D: Liver, H\&E staining.

\section{Discussion}

The present study identified $A$. hydrophila bacteria in Koi fish, which is known as one of the most critical lethal pathogens in various carp fish (9). Aeromonas bacteria are a part of the water's natural flora, as well as fish. Still, they can become opportunistic pathogens causing super-acute epidemics (e.g., Aeromonas hydrophila pathotype) under certain conditions, including environmental stresses. This event can cause considerable casualties in the aquaculture industry $(18,19)$, often occurring within a few hours of the disease onset (20). In the present study, it can be said that transport stress and reduced immune function of fish could have been contributors to the outbreak. This is in line with the notion that Aeromonas bacteria are opportunistic pathogens that can only cause disease in immunocompromised fish (21). In Iran, several studies have investigated $A$. hydrophila infection in various fish, including goldfish (22), angelfish (23), and common carp (24).

In the autopsy examination of the obtained samples, wounds and bleeding spots were evident on the body's surface, as well as the abdomen and internal organs. These findings were similar to the symp- toms observed in the study of Stratev et al. in 2015 (11). Many studies have shown that chronic infection with $A$. hydrophila is associated with ulcerative skin lesions and local bleeding and inflammation (10).

In our study, histological examinations showed multiple tissue damages in the gills, liver, and kidneys. These included necrosis, inflammation, and hemorrhage in the gills, inflammation in the kidney, necrosis, and nuclear pyknosis in hepatocytes. In several studies examining the histological features of $A$. hydrophila infection, similar findings have been reported $(11,25$ 29). In this regard, degenerative histological changes due to $A$. hydrophila infection have been reported in organs such as the gills, kidneys, and liver (10). Also, in line with the present study in which tissue damages in the gills were prominent, Al Yahya et al. (2018) (10) and Cookiyaei et al. (2012) (30) also reported necrosis in gill blades and hemorrhage in gills due to $A$. hydrophila infection. One of the significant issues in the histopathological features of $A$. hydrophila infection is that most tissue damage due to this bacterium has been observed in the liver and kidneys (11). In fact, the liver can be considered the target organ of $A$. hydrophila (10). In the histological evaluation of the 
kidney, similar to the study of Sellegounder et al. (2018), infiltration of inflammatory cells was observed (31). In a study considering Nile tilapia, bleeding foci were observed in the kidney due to a bacterial infection (32). In the examination of the liver and pancreas tissues, we noticed vacuolation and nuclear pyknosis, as well as the necrosis of hepatocytes and pancreatic cells, which were similar to the results of other studies $(10,31,33)$. In a study, Afifi et al. (2000) attributed these changes to the toxins and extracellular compounds released by $A$. hydrophila, including hemolysin, proteases, and elastase, in the liver, leading to severe tissue damage and necrosis (34).

\section{Conclusion}

The results of the present study showed that freshwater fish are always prone to Aeromonas spp. infections. According to our research, pathological changes in the gills, liver, and kidneys can be suitable biomarkers for assessing the pathogenicity of $A$. hydrophila in Koi fish. In addition, Aeromonas species can be a threat to public health, especially for those who are in contact with sick fish. Therefore, the proper management of water quality and food health and the quarantine of new fish can play a significant role in preventing and controlling $A$. hydrophila infection in fish and avoiding its transmission to humans.

\section{Acknowledgment}

We sincerely thank all the colleagues at Razaf Research Center who assisted us in conducting this research.

Conflict of Interest The authors declared no conflicts of interest. 


$$
\begin{aligned}
& \text { مجله ميكروبشناسى يزشكى ايران }
\end{aligned}
$$

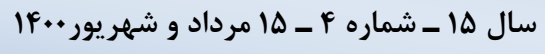

$$
\begin{aligned}
& \text { Journal homepage: www.ijmm.ir }
\end{aligned}
$$

\title{
جداسازى أئروموناس هيدروفيلا و بررسى اثرات آسيبشناسى ناشى از اين پاتوزن
}

\section{در ماهى كوى (Cyprinus carpio)}

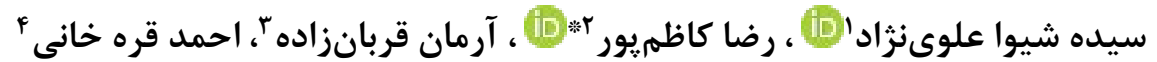

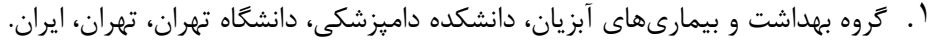

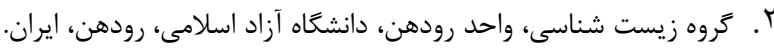

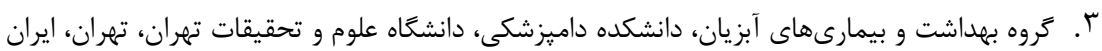

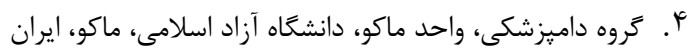

\begin{tabular}{|c|}
\hline جكيله \\
\hline 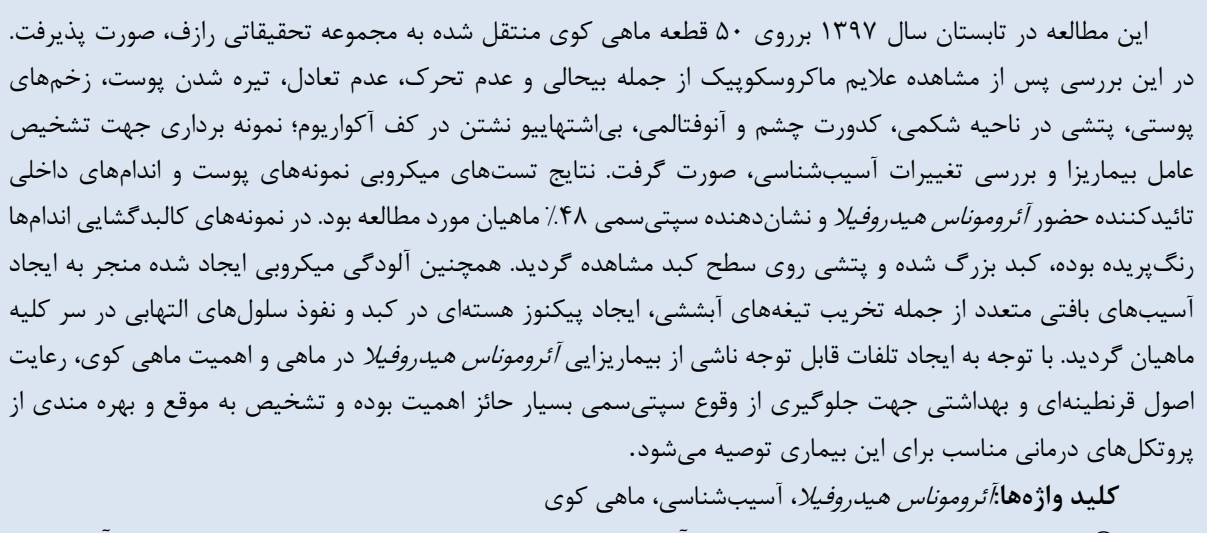 \\
\hline
\end{tabular}

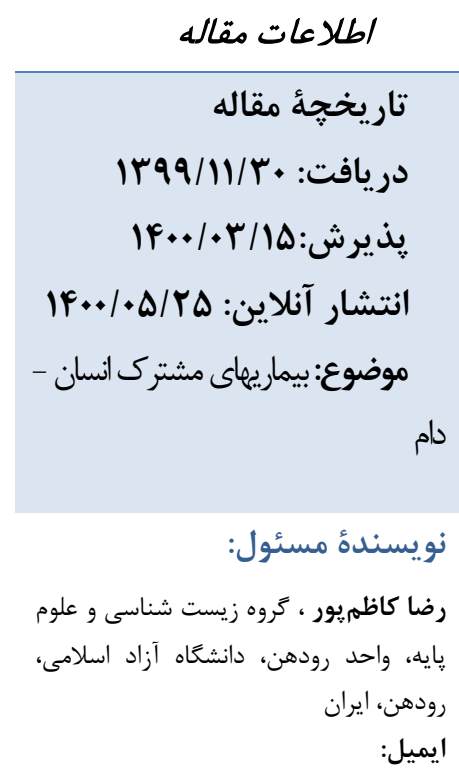

or.kazempoor@riau.ac.ir
كيور، تيلاييا، گربه ماهى و سالمون، بيمارى لكه قرمز در باس و كيور

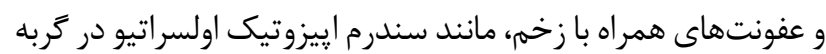
ماهى، كاد و كيور مشاركت دارد ( (ه). سيتىسمى آئروموناسى عموما هنگامى ايجاد مىشود كه ماهيان تحت شرايط استرسزا از جمله دماى بالاى آب، كيفيت بد آب، هييوكسى، عفونتهاى انگلى، تراكم بالا، دستكارى و حمل و نقل باشند (و, V) و باعث ايجاد علايم التهاب مزمن براى جند هفته مىشود كه طى آن ميزان مرى و مير بلهورتدريجى افزايش مىيابد، مرگ و مير همراه با اين عفونت باكتريايى و نيز هزينههاى كنترل و درمان، منجر به تحميل

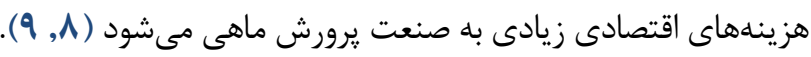

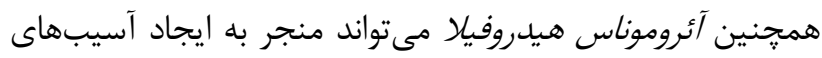

مقدمه

آئروموناس هيدروفيلا يك باكترى ميلهاى گرم منفى است كه بلهورمشخص در محيطهاى آبى و همجنين در آب آشاميدنى، فاضلاب، و غذا يافت مىشود (1). اين باكترى را مىتوان از آب مصبها، آب شور دريا و آب شيرين جداسازى كرد (ا-ب). محيطهاى آب شيرين، به ويزه انواع حاوى مقادير بالاى مواد معدنى،

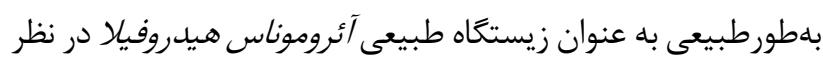
كرفته مىشوند، اما شواهد اخير نشان مىدهد كه اين اركانيسم همجنين مىتواند جزيى از فلور رودهاى ماهى ها نيز باشد (F). اين باكترى يك ياتورن شناخته شده در ماهيان است كه طيف

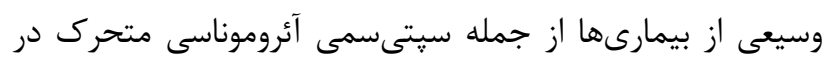

Majallah-i mīkrub/shināsī-i pizishkī-i İrān.

FV. 
علايیم بالينى از هر تانك (در مجموع ضَّ ماهى) به صورت كاملا تصادفى صيد شده و يس از بيهوشى توسط يودر گل ميخك نمونه بردارى از يوست اندامهاى داخلى براى شناسايى عامل بيمارىزا و انجام عمليات

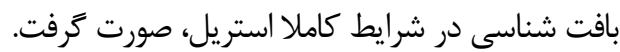

نمونههاى اخذ شده از كبد، آبشش و كليه ماهيان ابتدا توسط سرم فيزيولوزى شستوشو داده شده و سيس با استفاده از هموزنيزاتور

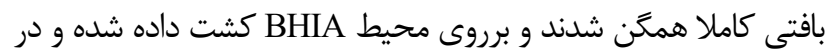

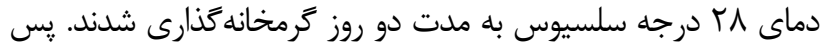
از مرحله كَمخانهَذارى يرَّنهاى رشد يافته را مجدد بر روى محيط

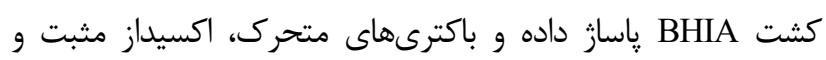
تخميركننده كلوكز بهعنوان موارد مشكوك به آئروموناس مورد بررسىهاى بيوشيميايى و فيزيولوزيكى قرار گرفتند. تستهاى تاييدى انجام شده در اين مرحله شامل توليد H2S، اوره آز، احياى سيترات، توليد اندول، احياى نيترات، رشد در محيط مك كانكى و تخمير كربوهيدراتها (كلوكز، اينوزيتول، سوكرز، سوربيتول، آرتبينوز، مانيتول)

براى بررسىهاى بافت شناسى نمونههاى آبشش، كبد و كليه

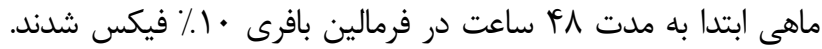
سيس نمونههاى فيكسشده يس از طى مرحله آبخيرى و شفاف سازى بـ بـ

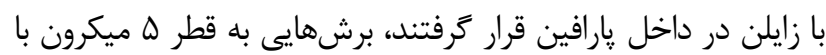
استفاده از دستخاه ميكروتوم تهيه شده و رنتَآميزى هماتوكسيلين - بارئ ائوزين (H\&E) انجام شد. لامهاى بافت شناسى تهيهشده با استفاده از

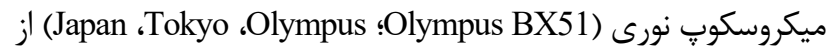

$$
\text { نظر آسيبشناسى بررسى شد (IV). }
$$

نتايج تستهاى ميكروبى نشاندهنده سيتىسمى YA درصدى ( TF نمونه) أتروموناس هيدروفيلا در ماهيان مورد مطالعه بود (شكل I). در نمونههاى كالبدگثايى علاوه بر تيرگى، يتشى و ضايعات اولسراتيو

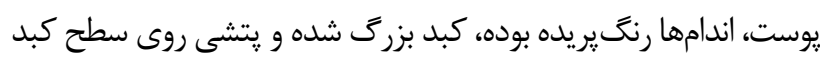
مشاهده گرديد (شكل ז.). و در بررسىهاى ميكروسكوييك آسيبهاى بوده مشاهده شده در آبشش شامل به هم جسبيدن تيغههاى آبششى ثانويه،

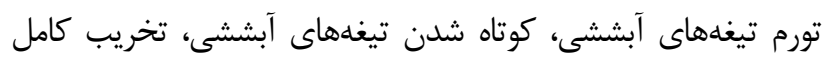

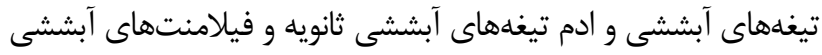
بود. علاوه بر اين جدا شدن إيتليال با جدا شدن لايه خارجى إيتليوم لاملار مشاهده شد و احتقان در تيغههاى آبششى اوليه و ثانويه كاملا مشخص بود (شكلr. A,B). در سر كليه، نفوذ سلولهاى التهابى (نوتروفيل) مشهود است كه اين سلولها در عروق و گارانشيم ديده

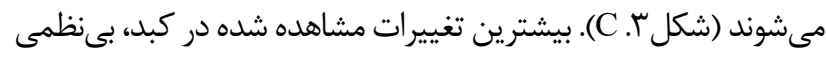

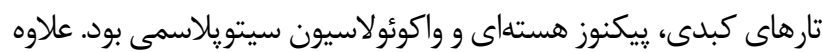

بافتى موضعى از جمله تخريب بافتى و التهاب در ميزبان شود (•ا,

نكته قابل توجه ديگر در رابطه با اين باكترى اين است كه اين ياتوزن مىتواند يك بيمارى زئونوتيك بوده و علاوه بر ماهىها، دوزيستان و خزند

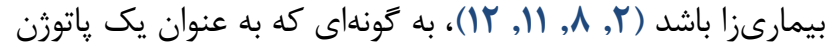
نوظهور در انسان شناخته مىشود (1). در نتيجه حضور آئروموناس

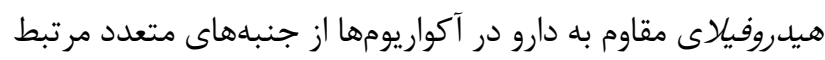
با سلامت عمومى داراى اهميت است (ب) (I). أهى كوى (fancy carp Cyprinus carpio L. var. koi) جمله ماهيان زينتى آب شيرين كران قيمت است كه اغلب دجار

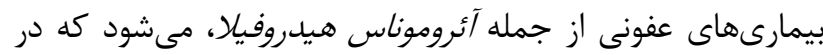

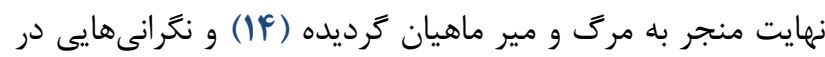
مورد تاثيرات محيطى (ه|) و مخاطرات زئونوتيك (سا) ايجاد كرده است. با توجه به مطالب ذكر شده و اهميت ماهى كوى و ياتوزن آئروموناس هيدروفيلا در ايجاد بيمارى و تلفات در جمعيت ماهيان، در مطالعه حاضر يس شناسايى باكترى آئروموناس هيدروفيلا از

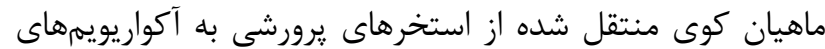
مجموعه تحقيقاتى با استفاده از روشهاى كشت ميكروبى، براى شناسايى علايم ياتولوزيك ناشى از اين بيمارى در اين ماهى زينتى

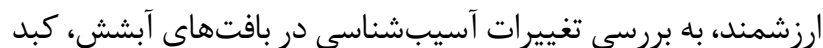
و كليه يرداختيم.

تزارش مورد

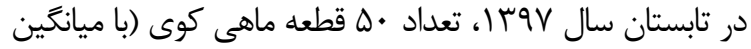

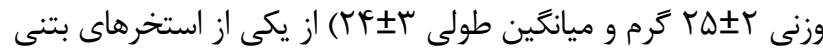
مركز تكثير و يرورش ماهى كوى در شهرستان شهريار به مركز علمى يروهشى رازف، دانشخاه علوم و تحقيقات تهران، ايران، انتقال يافت.

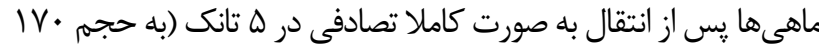

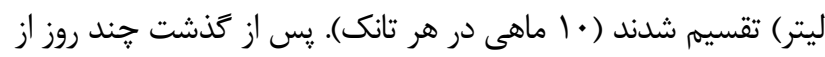
انتقال، تمامى ماهىها داراى علايم ماكروسكوبيكى مشابه از جمله تيره شدن يوست، يتشى (هماتوم) در ناحيه شكمى، زخمهاى يوستى،

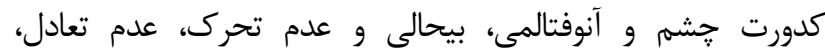
بى اشتهايى و نشستن در كف آكواريوم بودند. با مشاهده علايم بالينى اقدامات لازم براى نمونهبردارى كشت ميكروبى از يوست و اندامهاى داخلى بدن ماهيان و همزمان كالبدَشايى و نمونهبردارى براى بررسىهاى آسيبشناسى انجام يذيرفت. با توجه به آنكه اين مطالعه به

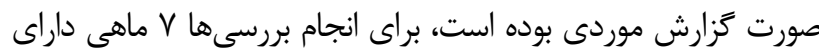


بر اين، درجات مختلف دزنراسيون سلولهاى پانكراس نيز در جندين

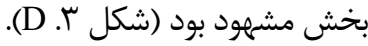

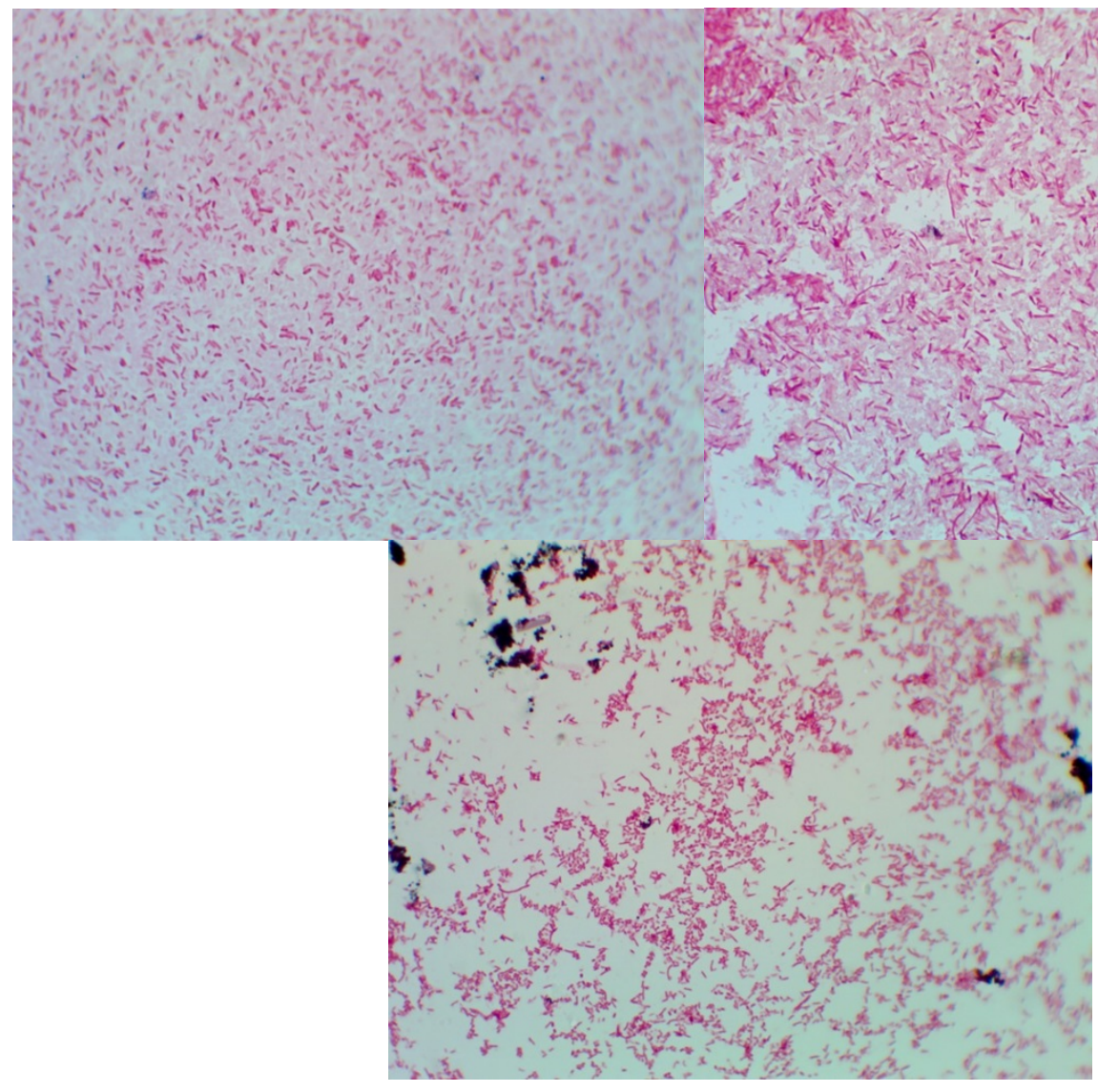

شكل ا. شناسايى باكترى آئروموناس هيدروفيلا در نمونههاى مورد مطالعه 


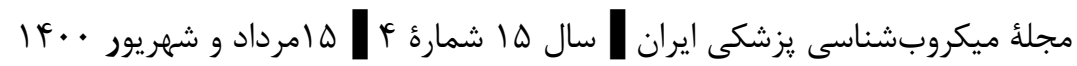

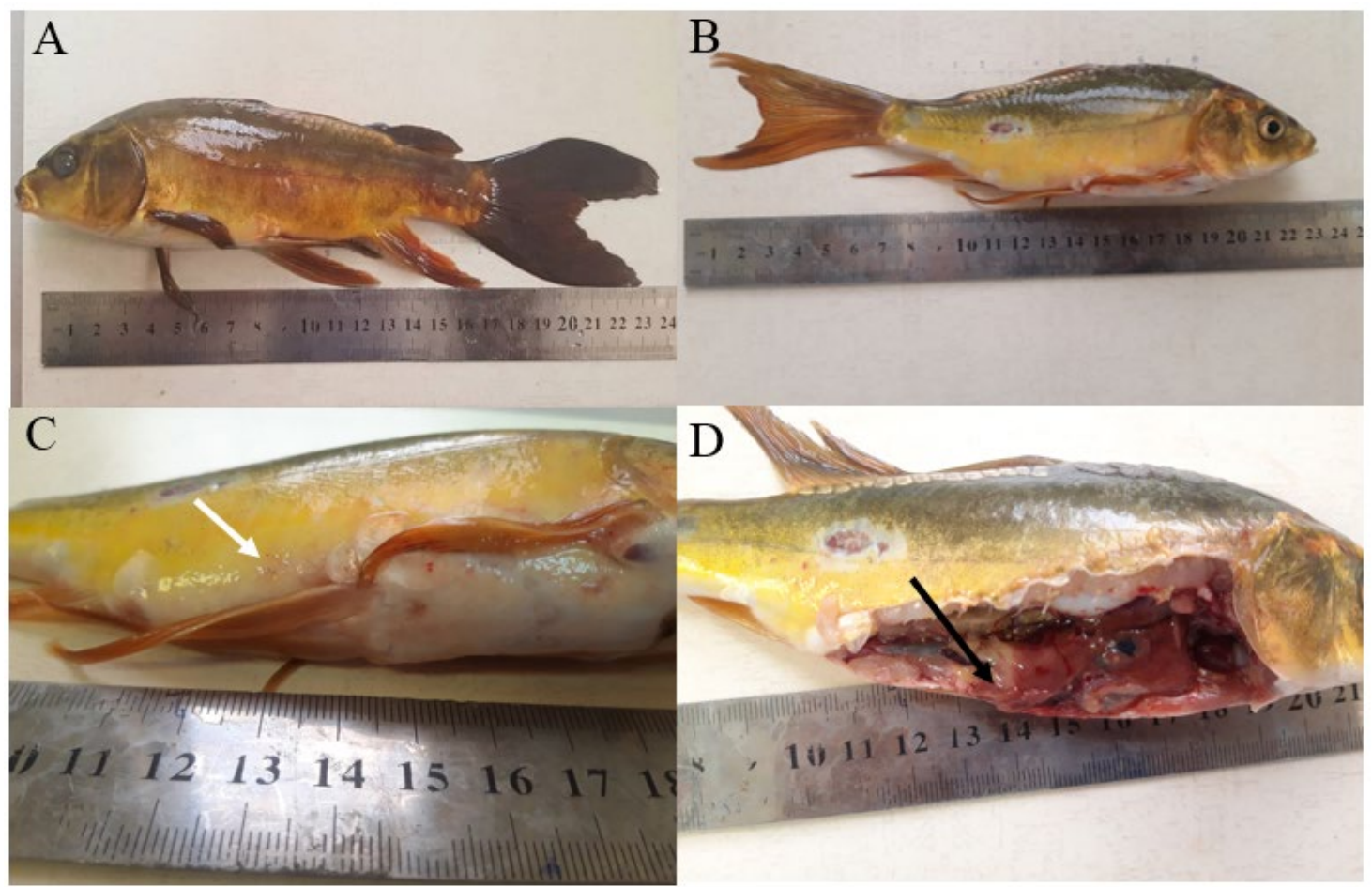

شكل ז. تيره شدن سطح بدن (A)، ضايعات اولسراتيو يوست(B)، فلش سفيد: يتشى روى سطح يوست (C)، بزر شَ شدن كبد، رنخَ بريدَى اندامها، فلش سياه: (D) تشى سطح كبد
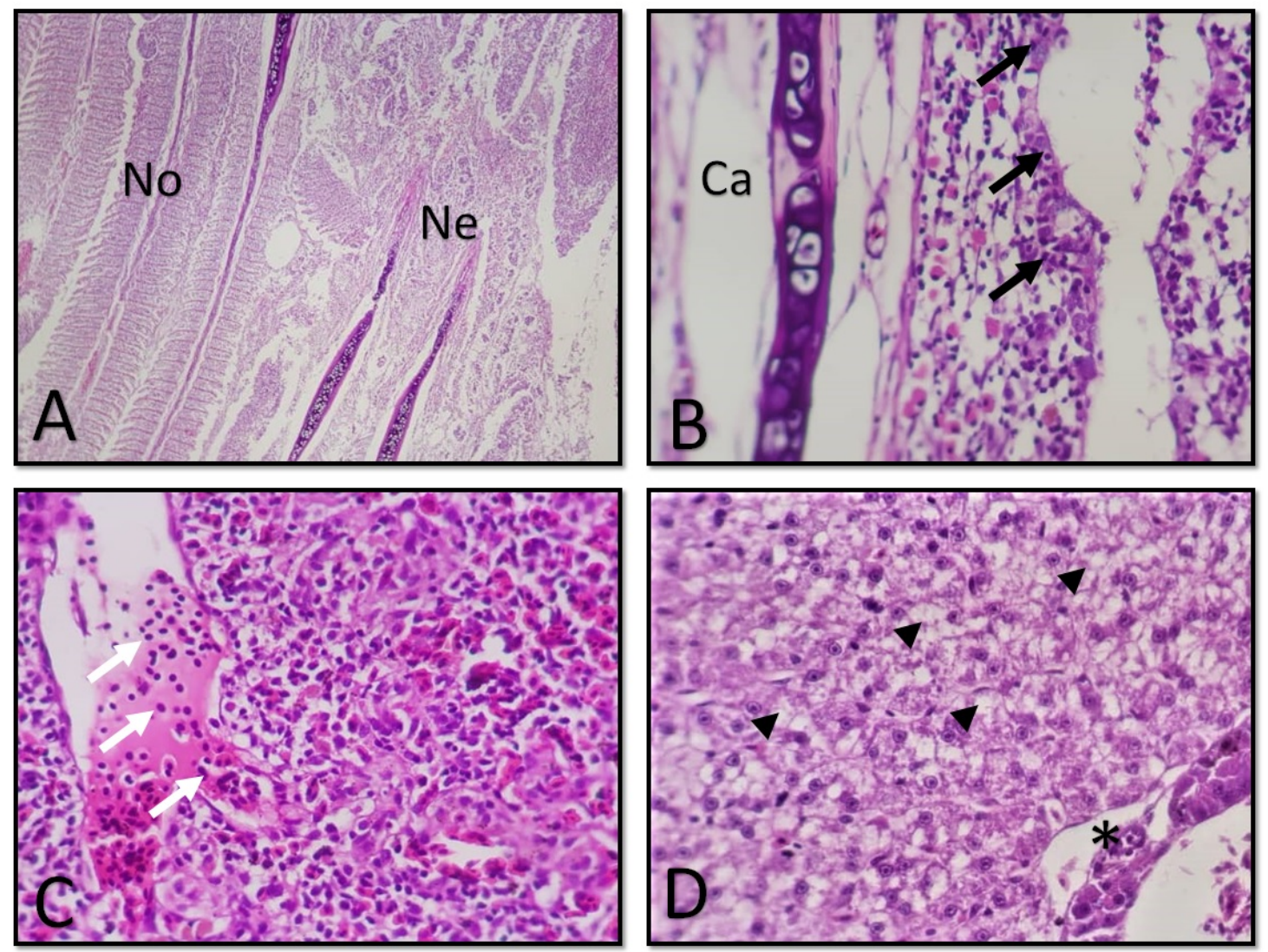

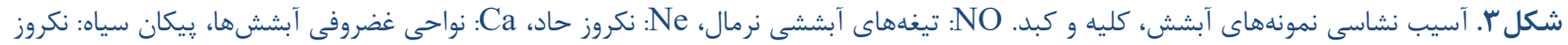

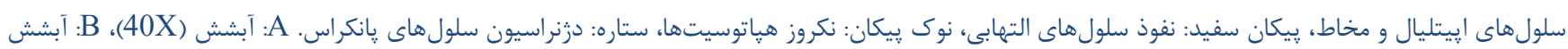

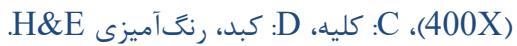


نكروز تيغههاى آبششى و خونريزى در بافت آبشش را دان در نتيجه

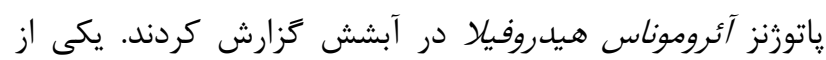

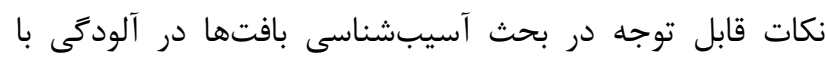
أئروموناس هيدروفيلا اين است كه بيشترين آسيب بافتى در نتيجه

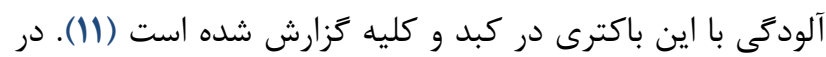

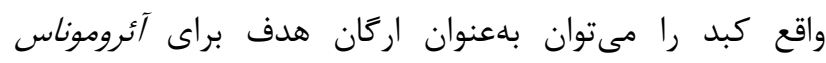

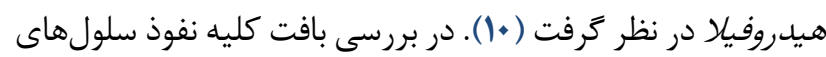

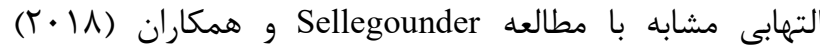
مشاهده شد (آ⿱一) و در تيلإِياى نيل، كانونهاى خونريزى در كليهها بر اثر عفونت باكتريايى مشاهده شد (Tr). بافت كبد و يانكراس در مطالعه حاضر نشان دهنده واكوئولاسيون، رِيكنوز

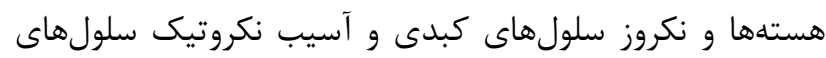
يانكراس بود كه اين علايم در مطالعات متعددى مشاهده شد (•)

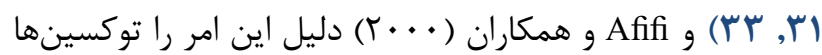
و تركيبات خارج سلولى توليدشده بهوسيلة آثروموناس هيدروفيلا (از جمله هموليزين، يروتئاز و الاستاز) در كبد بيان كردند كه منجر تيدات

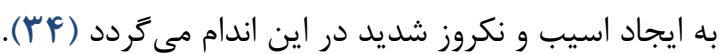
نتايج اين مطالعه نشان مىدهد ماهيان آب شيرين هميشه

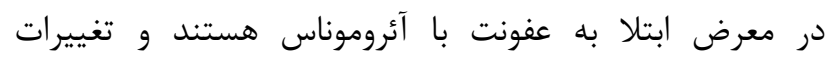

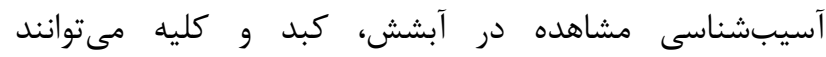
بيوماركرهاى خوبى براى ارزيابى بيماريزايى آئروموناس هيدروفيداسيلا

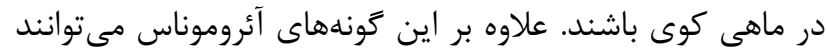

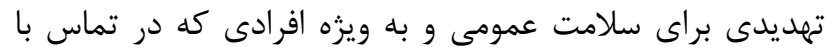
ماهيان بيمار هستند، به حساب بيايد. فلذا مديريت مناسب كيدي كيفيت فيدي

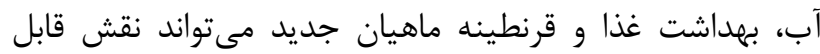

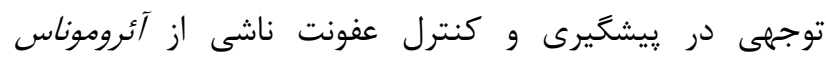

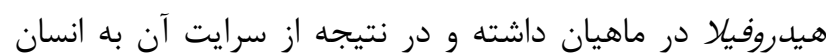

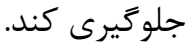

$$
\text { سياسگزارى }
$$

بدينوسيله از تمامى همكاران در مركز تحقيقاتى رازف كه ما

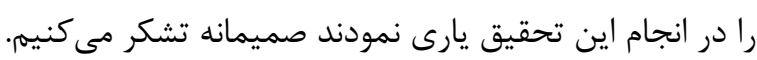

$$
\text { تعارض در منافع }
$$

هيج كَونه تعارضى در منافع از سوى نويسندكان اعلام نشده است.

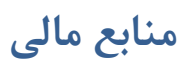

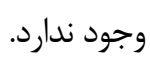

بحث و نتيجه كيرى

نتيجه تحقيق حاضر به شناسايى باكترى آئروموناس

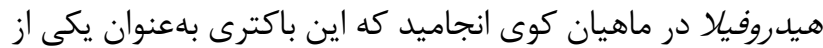

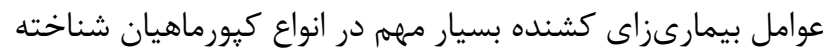
شده است (9). آئروموناسها جزو فلور طبيعى آبهار و بدن مارن ماهيان هستند اما در شرايط خاصى از جمله استرسهاى محيطى التى مىتوانند به ياتوزنهاى فرصت طلبى تبديل شوند كه با ايجاد

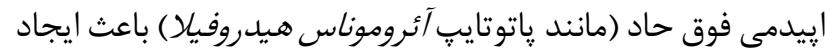

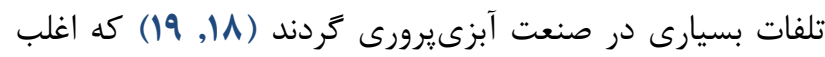

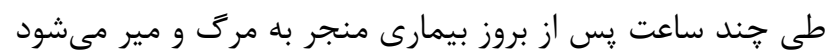
(†)، به اين ترتيب در مطالعه حاضر مى توان استرس حمل و نقل

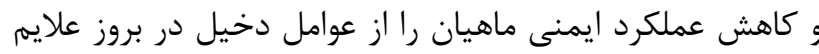

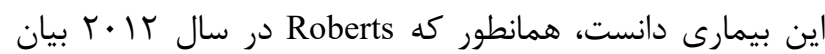

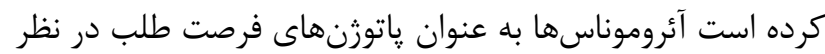
كرفته مىشوند كه تنها قادر به ايجاد بيمارى در جمعيتهاى ضعيف شده ماهىها هستند (آI). در اين رابطه در ايران مطالعات

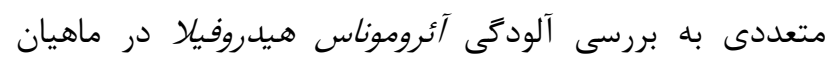

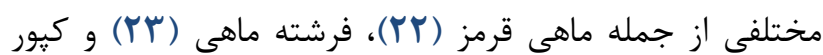

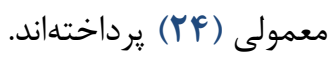

در بررسى كالبدگشايى نمونهاى اخذ شده شاهد زخم و نقاط خونريزى روى سطح بدن، بخش شكمى ماهى و اندامهاى داخلى

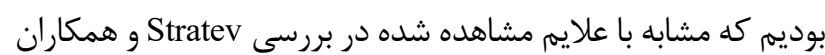
در سال ها • r بوده (1) و مطالعات بسيارى نشان دادهاند كه عفونت

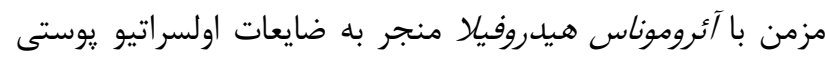
همراه با خونريزىهاى كانونى و التهاب شده است (•(1). نتايج بافتشناسى اين مطالعه نشاندهنده آسيب بافتى آنى متعدد در اركانهاى آبشش، كبد و كليه بود كه از آن جمله مى آنوان به نكروز، التهاب و خونريزى در بافت آبشش، التهاب در بافت كليه

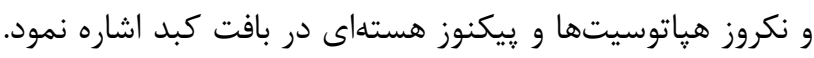
اين در حالى است كه مطالعات متعددى به بررسى آلودگى ماهيان

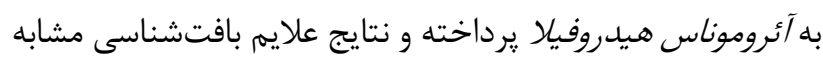

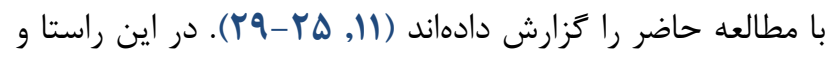

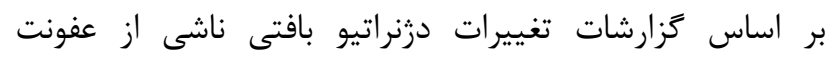
أئروموناس هيدروفيلا بهطورشايع در اركانهايى مانند آبشش، كليه و كبد ديده مىشوند (•) و همانطور كه در مطالعه حاضر شاهد

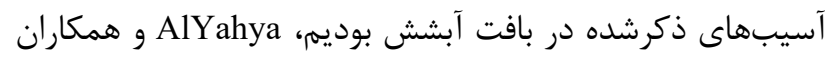

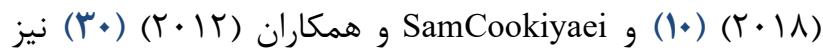




\section{Referance}

1. Janda JM, Abbott SL. The genus Aeromonas: taxonomy, pathogenicity, and infection. Clin Microbiol Rev. 2010;23(1):35-73. [PMID] [PMCID]

[DOI:10.1128/CMR.00039-09]

2. Trott D. Veterinary Microbiology: Bacterial and Fungal Agents of Animal Disease-By J. Glenn Songer, KW Post. Brisbane, Australia: The University of Queensland; 2006. [DOI:10.1111/i.1751-0813.2006.00082.x]

3. Dias MK, Sampaio LS, Proietti-Junior AA, Yoshioka ET, Rodrigues DP, Rodriguez AF, et al. Lethal dose and clinical signs of Aeromonas hydrophila in Arapaima gigas (Arapaimidae), the giant fish from Amazon. Vet Microbiol. 2016;188:12-5. [DOI:10.1016/j.vetmic.2016.04.001] [PMID]

4. Sreedharan K, Philip R, Singh ISB. Virulence potential and antibiotic susceptibility pattern of motile aeromonads associated with freshwater ornamental fish culture systems: a possible threat to public health. Brazil J Microbiol. 2012;43(2):754-65. [DOI:10.1590/S151783822012000200040] [PMID] [PMCID]

5. Holmes P, Niccolls LM, Sartory D. The ecology of mesophilic Aeromonas in the aquatic environment. The Genus Aeromonas. 1996:127-50.

6. Stratev D, Odeyemi OA. An overview of motile Aeromonas septicaemia management. Aquacult Int. 2017;25(3):1095-105. [DOI:10.1007/s10499-0160100-3]

7. Saavedra MJ, Guedes-Novais S, Alves A, Rema P, Tacão $\mathrm{M}$, Correia A, et al. Resistance to beta-lactam antibiotics in Aeromonas hydrophila isolated from rainbow trout (Oncorhynchus mykiss). Int Microbiol. 2004;7(3):207-11.

8. Plumb JA, Hanson LA. Health maintenance and principal microbial diseases of cultured fishes. New Jersey: John Wiley \& Sons; 2010. [DOI:10.1002/9780470958353]

9. Zhang D, Moreira GS, Shoemaker C, Newton JC, Xu D-H. Detection and quantification of virulent Aeromonas hydrophila in channel catfish tissues following waterborne challenge. FEMS Microbiol Lett. 2016;363(9). [DOI:10.1093/femsle/fnw080] [PMID]

10. AlYahya SA, Ameen F, Al-Niaeem KS, Al-Sa'adi BA, Hadi S, Mostafa AA. Histopathological studies of experimental Aeromonas hydrophila infection in blue tilapia, Oreochromis aureus. Saudi J Biol Sci. 2018;25(1):182-5. [DOI:10.1016/i.sjbs.2017.10.019] [PMID] [PMCID]

11. Stratev D, Stoev S, Vashin I, Daskalov H. Some varieties of pathological changes in experimental infection of carps (Cyprinus carpio) with Aeromonas hydrophila. J Aquacult Eng and Fish Res. 2015;1(4):191-202. [DOI:10.3153/JAEFR15019]

12. Guz L, Kozinska A. Antibiotic susceptibility of Aeromonas hydrophila and A. sobria isolated from farmed carp (Cyprinus carpio L.). Bullet Vet Ins Pulawy. 2004;48:3915.

13. Weir M, Rajić A, Dutil L, Cernicchiaro N, Uhland F, Mercier B, et al. Zoonotic bacteria, antimicrobial use and antimicrobial resistance in ornamental fish: a systematic review of the existing research and survey of aquacultureallied professionals. Epidemiol Infect. 2012;140(2):192206. [DOI:10.1017/S0950268811001798] [PMID]

14. Lin S, Mao S, Guan Y, Luo L, Luo L, Pan Y. Effects of dietary chitosan oligosaccharides and Bacillus coagulans on the growth, innate immunity and resistance of Koi (Cyprinus carpio koi). Aquaculture. 2012;342:36-41. [DOI:10.1016/j.aquaculture.2012.02.009]

15. Matsui K, Honjo M, Kohmatsu Y, Uchii K, Yonekura R, Kawabata Zi. Detection and significance of koi herpesvirus (KHV) in freshwater environments. Freshwater Biol. 2008;53(6):1262-72. 2427.2007.01874.x]

[DOI:10.1111/i.1365-

16. Mzula A, Wambura PN, Mdegela RH, Shirima GM. Phenotypic and molecular detection of Aeromonads infection in farmed Nile tilapia in Southern highland and Northern Tanzania. Heliyon. 2019;5(8):e02220. [DOI:10.1016/i.heliyon.2019.e02220] [PMID] [PMCID]

17. Pirarat N, Pinpimai K, Endo M, Katagiri T, Ponpornpisit A, Chansue N, et al. Modulation of intestinal morphology and immunity in nile tilapia (Oreochromis niloticus) by Lactobacillus rhamnosus GG. Res Vet Sci. 2011;91(3):e92-e7. [DOI:10.1016/i.rvsc.2011.02.014] [PMID]

18. Hemstreet B. An update on Aeromonas hydrophila from a fish health specialist for summer 2010. Catfish Journal. 2010;24(4).

19. Nielsen ME, Høi L, Schmidt A, Qian D, Shimada T, Shen $\mathrm{J}$, et al. Is Aeromonas hydrophila the dominant motile Aeromonas species that causes disease outbreaks in aquaculture production in the Zhejiang Province of China? Dis Aquat Org. 2001;46(1):23-9. [DOI:10.3354/dao046023] [PMID]

20. Beaz-Hidalgo R, Martínez-Murcia A, Figueras MJ. Reclassification of Aeromonas hydrophila subsp. dhakensis Huys et al. 2002 and Aeromonas aquariorum Martinez-Murcia et al. 2008 as Aeromonas dhakensis sp. nov. comb nov. and emendation of the species Aeromonas hydrophila. Syst Appl Microbiol. 2013;36(3):171-6. [DOI:10.1016/i.syapm.2012.12.007] [PMID]

21. Roberts RJ. Fish pathology. New Jersey: John Wiley \& Sons; 2012. [DOI:10.1002/9781118222942]

22. Fadaeifard F. Molecular detection of Aeromonas hydrophila in the aquarium gold fish and cultured rainbow trout in Chaharmahal va Bakhtiary province. Vet Clin Pathol. 2014;8(1 ):401-9.

23. Peyghan R, Tulaby Dezfuly Z, Moori Bakhtiari N, Ahangarzadeh M, Haghparast M. A case study of aeromonas septicemia coincides with infection to hexamita sp. and capillaria sp. In a stock of angle fish, pterophyllum scalare. Vet Res Biol Prod. 2016;29(2 ):117-21.

24. Hosseinzadeh M, Tukmechi A. Isolation and identification of enterotoxin producing Aeromonas hydrophila from common carp (Cyprinus carpio). J Anim Environ. 2016;7(4):173-8 
25. Abdelhamed H, Ibrahim I, Baumgartner W, Lawrence ML, Karsi A. Characterization of histopathological and ultrastructural changes in channel catfish experimentally infected with virulent Aeromonas hydrophila. Front Microbiol. $2017 ; 8: 1519$ [DOI:10.3389/fmicb.2017.01519] [PMID] [PMCID]

26. Alsaphar SA. Detection and study of the experimental infection of Aeromonas strain in the common carp (Cyprinus carpio L.). Iraqi J Vet Med. 2012;36(2):222-30. [DOI:10.30539/iraqijvm.v36i2.500]

27. Khamees ES, Al-Rudainy AJ, Faleh EB. Study of Histopathological Changes in the Common Carp (Cyprinus carpio) Experimentally Infected by Bacteria Aeromonas hydrophila. Basrah J Agri Sci. 2013;26. [DOI:10.33762/bagrs.2013.112076]

28. Kumar R, Pande V, Singh L, Sharma L, Saxena N, Thakuria D, et al. Pathological findings of experimental Aeromonas hydrophila infection in golden mahseer (Tor putitora). Fish Aquacult J. 2016;7(160):2 .

29. Hamid NH, Hassan M, Sabri MM, Hasliza A, Hamdan RH, Afifah MN, et al., editors. Studies on Pathogenicity Effect of Aeromonas hydrophila Infection in Juvenile Red Hybrid Tilapia Oreochromis sp. Proceedings of international seminar on livestock production and veterinary technology; 2016. [DOI:10.14334/Proc.Intsem.LPVT-2016p.532-539]
30. SamCookiyaei A, Afsharnasab M, Razavilar V, Motalebi A, Kakoolaki S, Asadpor Y, et al. Experimentally pathogenesis of Aeromonas hydrophila in freshwater Crayfish (Astacus leptodactylus) in iran. Iran J Fish Sci. 2012;11(3):644-56.

31. Sellegounder D, Gupta YR, Murugananthkumar R, Senthilkumaran B. Enterotoxic effects of Aeromonas hydrophila infection in the catfish, Clarias gariepinus: Biochemical, histological and proteome analyses. Vet Immunol Immunopathol. 2018;204:1-10. [DOI:10.1016/j.vetimm.2018.08.008] [PMID]

32. Yardimci B, AYDIN Y. Pathological findings of experimental Aeromonas hydrophila infection in Nile tilapia (Oreochromis niloticus). Ankara Üni Vet Fakülte Dergisi.

2011;58:47-54

\section{[DOI:10.1501/Vetfak 0000002448]}

33. Gupta S, Pal A, Sahu N, Dalvi R, Kumar V, Mukherjee S. Microbial levan in the diet of Labeo rohita Hamilton juveniles: effect on non-specific immunity and histopathological changes after challenge with Aeromonas hydrophila. J Fish Dis. 2008;31(9):649-57. [DOI:10.1111/j.1365-2761.2008.00939.x] [PMID]

34. Afifi S, Al-Thobiati S, Hazaa M. Bacteriological and histopathological studies on Aeromonas hydrophila infection of Nile tilapia (Oreochromis niloticus) from fish farms in Saudi Arabia. Assiut Vet Med J. 2000;42(84):195205. 